\title{
Selected individual differences as predictors of milk product consumption in a group of perimenopausal women in the light of health hazards
}

\author{
Niektóre różnice indywidualne jako predykłory konsumpcii produktów mlecznych w grupie kobiet w wieku \\ okołomenopauzalnym w świetle zagrożeń stanu zdrowia
}

\author{
Maria Gacek \\ Department of Sports Medicine and Human Nutrition, University School of Physical Education in Krakow \\ head of Department: dr hab. Zbigniew Szyguła, prof. nadzw.
}

Przegląd Menopauzalny 2013; 4: 300-306

\begin{abstract}
The aim of this study was to analyze the consumption frequency of dairy products depending on selected individual traits (level of self-efficacy, optimism, and satisfaction with life) in a group of perimenopausal women. The study, using the questionnaire for the assessment of food product consumption frequency, and psychological tests (GSES, LOT-R, SWLS), was conducted in a group of 320 women aged between 45 and 55. The Spearman's coefficients of rank correlation and the Kruskal-Wallis test with the Dunn test for multiple comparisons were used for statistical analysis $(p<0.05)$.

Statistical analysis revealed that the level of self-efficacy correlated positively with the consumption frequency of low-fat cottage cheese, kefir $(p<0.05)$, buttermilk and natural yoghurt $(p<0.01)$, and was inversely correlated with the consumption of high-fat milk and high-fat cottage cheese $(p<0.01)$. The level of optimism showed a positive correlation with the frequency of kefir and fruit yoghurt consumption $(p<0.05)$, and was inversely correlated with the consumption of high- and low-fat milk $(p<0.05)$ and high-fat cottage cheese $(p<0.01)$. An increased level of satisfaction with life was associated with a more frequent consumption of kefir $(p<0.05)$ and fruit yoghurt $(p<0.01)$, and with a lower consumption of high- and low-fat milk $(p<0.05)$ and high-fat cottage cheese $(p<0.01)$. The level of self-efficacy significantly influenced mean consumption frequency of high- $(p<0.0001)$ and low-fat milk $(p<0.05)$, high-fat cottage cheese, buttermilk, and natural $(p<0.0001)$ and fruit yoghurt $(p<0.01)$, and the levels of optimism and satisfaction with life exerted a significant effect on the frequency of consumption of high-fat milk, high-fat cottage cheese, and fruit yoghurt $(p<0.01)$. Overall, our study showed that the frequency of dairy product consumption among 45-55-year-old women is low and varies depending on the analyzed individual traits.
\end{abstract}

Key words: women, menopause, dietary pattern, milk products, psychological features.

\section{Streszczenie}

Celem badań była ocena częstości konsumpcji produktów mlecznych w zależności od niektórych cech indywidualnych (poziomu skuteczności, optymizmu i satysfakcji życiowej) w grupie kobiet w wieku okołomenopauzalnym. Badaniami, z wykorzystaniem kwestionariusza częstości spożycia produktów oraz testów psychologicznych (GSES, LOT-R, SWLS), objęto 320 kobiet w wieku 45-55 lat. W analizie statystycznej zastosowano korelacje rang Spearmana oraz testy Kruskala-Wallisa i Dunna $(p<0,05)$.

W analizie statystycznej poziom skuteczności wykazywał dodatnią korelację ze spożyciem twarogu półtłustego i kefiru $(p<0,05)$ oraz maślanki i jogurtu naturalnego $(p<0,01)$, a ujemną ze spożyciem tłustego mleka i tłustego twarogu $(p<0,01)$. Poziom optymizmu był dodatnio skorelowany z częstością spożycia kefiru i jogurtu owocowego $(p<0,05)$, a ujemnie ze spożyciem mleka tłustego i półtłustego $(p<0,05)$ oraz twarogu tłustego $(p<0,01)$. Ze wzrostem poziomu satysfakcji życiowej zwiększało się spożycie kefiru $(p<0,05)$ i jogurtu owocowego $(p<0,01)$, a spadało spożycie mleka tłustego i półtłustego $(p<0,05)$ oraz tłustego twarogu $(p<0,01)$. Porównanie średniej częstości konsumpcji produktów w zależności od cech psychologicznych wykazało, że poziom skuteczności różnicował spożycie mleka tłustego $(p<0,0001)$ i póttłustego $(p<0,05)$, 
twarogu tłustego, maślanki oraz jogurtu naturalnego $(p<0,0001)$ i owocowego $(p<0,01)$, a poziom optymizmu i satysfakcji życiowej - spożycie tłustego mleka i tłustego twarogu oraz jogurtu owocowego $(p<0,01)$. W grupie kobiet w wieku 45-55 lat wykazano niską częstość konsumpcji produktów mlecznych, zróżnicowaną w zależności od analizowanych cech indywidualnych.

Słowa kluczowe: kobiety, menopauza, sposób żywienia, produkty mleczne, cechy psychologiczne.

\section{Introduction}

Everyday consumption of dairy products is included in Polish, American and Western European current dietary guidelines. According to the Harvard pyramid of healthy eating (2005), 1-2 servings of low-fat dairy products are recommended on a daily basis, while the frequencies recommended in the Polish pyramid, developed by the National Food and Nutrition Institute (2009), and in that of the Swiss Society for Nutrition (2005) correspond to 2 and 2-3 servings per day, respectively [1]. Milk and its products constitute a group of foods with high nutrient density, which results mostly from their contents of complete protein, calcium, and riboflavin [2]. High nutritional value makes these products important in the dietary prevention of some degenerative disorders, mostly osteoporosis, but also arterial hypertension and some neoplasms [3]. An increased risk of diet- and hormone-dependent chronic conditions, such as osteoporosis, diabetes, cardiovascular disorders and neoplasms, in postmenopausal women [4-8] stimulated research on the consumption of milk and its products as foods playing an important role in the prevention of these conditions. Active involvement of humans in achieving health-related objectives, reflected by a healthy style of life, including rational eating behaviors, is determined by a wide spectrum of socioeconomic, cultural, and personality-related factors [9-11]. This substantiates research on selected individual determinants of dietary choices in menopausal women, who are potentially exposed to the health threats mentioned above.

The aim of this study was to analyze some individual determinants of nutrition with regard to the consumption frequency of basic dairy products in a group of perimenopausal women. We analyzed selected individual characteristics, including the level of general selfefficacy, optimism, and satisfaction with life.

\section{Material and methods}

The study was conducted between 2010 and 2012 in a group of 320 women aged between 45 and 55. All the participants were professionally active employees of various offices in the Małopolska region. They all performed intellectual work, and had secondary (70\%) or higher education (30\%); most of them were married $(80 \%)$. Due to the principal objective of the study, a group homogenous in terms of sociodemographic characteristics was selected.
The frequency of consumption of dairy products was analyzed using a 7-item scale containing the following categories: several times a day (corresponding to 7 points), once a day (6 pts), several times a week (5 pts), once a week (4 pts), several times a month (3 pts), once a month (2 pts), and rarer/never (1 pt). Body mass index (BMI) was calculated on the basis of somatic measurements of body weight and body height. The levels of individual traits were determined with the validated tests: i) General Self-Efficacy Scale (GSES) by R. Schwarzer, M. Jerusalem and Z. Juczyński, ii) Life Orientation Test (LOT-R) by M. F. Scheier, Ch.S. Carver and M. W. Bridges, adapted by R. Poprawa and Z. Juczyński, and iii) Satisfaction with Life Scale (SWLS) by Ed Diener, R.A. Emmons, R.J. Larson and S. Griffin, adapted by Z. Juczyński. GSES was used to determine the level of general self-efficacy, while the optimistic disposition and overall satisfaction with life were measured with LOT-R and SWLS, respectively. The examined women were classified into the groups with low, moderate and high levels of self-efficacy, optimism, and satisfaction with life on the basis of relevant provisional Polish sten (standard ten) norms for adults [12].

Statistical analysis of results was conducted with PQStat ver. 1.4.2.324 software. The relationship between body mass index (BMI), GSES, LOT-R and SWLS scales (levels of self-efficacy, optimism and satisfaction with life) and the frequency of consumption of dairy products was estimated on the basis of Spearman's coefficients of rank correlation. The mean frequencies of consumption of dairy products associated with various levels of analyzed individual traits were compared with the KruskalWallis test with the Dunn test for multiple comparisons. Test probability was considered significant at $p<0.05$.

\section{Results}

Buttermilk was the food product which the examined women consumed least frequently, i.e. less often than once a month (2.24). High-fat cottage cheese (2.68) and high-fat milk (2.78) were ingested slightly less often than several times per month. Kefir (3.36), low-fat milk (3.49), natural yoghurt (3.60), and low-fat cottage cheese (3.65) were consumed more frequently than several times per month. Fruit yoghurts were the most frequently consumed dairy products with a declared frequency of consumption corresponding to once a week on average (3.78) (Table I). 
Table I. Consumption of dairy products in a group of menopausal women, grouped in an ascending order (descriptive statistics)

\begin{tabular}{lccccccc}
\hline & \multicolumn{7}{c}{ Descriptive statistics } \\
\cline { 2 - 10 } Product & Mean & $\begin{array}{c}\text { Standard } \\
\text { deviation }\end{array}$ & Minimum & $\begin{array}{c}\text { Lower } \\
\text { quartile }\end{array}$ & Median & $\begin{array}{c}\text { Upper } \\
\text { quartile }\end{array}$ & Maximum \\
\hline Buttermilk & 2.24 & 1.59 & 1.00 & 1.00 & 1.00 & 3.00 & 6.00 \\
\hline High-fat cottage cheese & 2.68 & 1.57 & 1.00 & 1.00 & 3.00 & 4.00 & 7.00 \\
\hline High-fat milk & 2.78 & 1.78 & 1.00 & 1.00 & 3.00 & 4.00 & 7.00 \\
\hline Kefir & 3.36 & 1.63 & 1.00 & 2.00 & 3.00 & 5.00 & 7.00 \\
\hline Low-fat milk & 3.49 & 2.05 & 1.00 & 1.00 & 4.00 & 5.00 & 7.00 \\
\hline Natural yoghurt & 3.60 & 1.75 & 1.00 & 2.00 & 4.00 & 5.00 & 7.00 \\
\hline Low-fat cottage cheese & 3.65 & 1.29 & 1.00 & 3.00 & 4.00 & 5.00 & 6.00 \\
\hline Fruit yoghurt & 3.78 & 1.65 & 1.00 & 3.00 & 4.00 & 5.00 & 7.00 \\
\hline
\end{tabular}

Statistical analysis revealed that higher BMI was associated with a significantly less frequent consumption of kefir and natural yoghurt $(p<0.01)$. The level of selfefficacy correlated positively with the consumption frequency of low-fat cottage cheese, kefir $(p<0.05)$, buttermilk and natural yoghurt $(p<0.01)$, and was inversely correlated with the consumption of high-fat milk and high-fat cottage cheese $(p<0.01)$. The level of optimism showed a positive correlation with the frequency of kefir and fruit yoghurt consumption $(p<0.05)$, and was inversely correlated with the consumption of high- and lowfat milk $(p<0.05)$ and high-fat cottage cheese $(p<0.01)$. An increased level of satisfaction with life was associated with a more frequent consumption of kefir $(p<0.05)$ and fruit yoghurt $(p<0.01)$, and with a lower consumption of high- and low-fat milk $(p<0.05)$, and high-fat cottage cheese $(p<0.01)$. The remaining analyzed coefficients of correlation were insignificant $(p>0.05)$ (Table II).

The level of self-efficacy significantly influenced mean consumption frequency of high- $(p<0.001)$ and low-fat milk $(p<0.05)$, high-fat cottage cheese, buttermilk, and natural $(p<0.0001)$ and fruit yoghurt $(p<0.01)$ among the studied women. The level of optimism also exerted a significant effect on the frequency of consumption of high-fat milk, high-fat cottage cheese, and fruit yoghurt $(p<0.01)$. Moreover, mean frequencies of the consumption of high-fat milk, high-fat cottage cheese, and fruit yoghurt differed significantly depending on the level of satisfaction with life in examined women $(p<0.01)$. Women characterized by a high level of self-efficacy declared drinking high-fat milk significantly less frequently than those with a moderate $(p<0.0001)$ and low level of this trait $(p<0.05)$. Moreover, high-fat milk was consumed less often by participants showing a high rather than moderate level of optimism $(p<0.01)$, and by those declaring a high level of satisfaction with life, rather than by moderately satisfied ones $(p<0.01)$. In turn, women with a high level of self-efficacy chose low-fat milk significantly more often than those characterized by low self-efficacy $(p<0.05)$. Women with a high level of selfefficacy preferred high-fat cottage cheese significantly less often than those with moderate $(p<0.0001)$ or low self-efficacy $(p<0.0001)$. Moreover, high-fat cottage cheese was consumed less frequently by women characterized by a low rather than high level of optimism $(p<0.01)$, and by those with high rather than moderate $(p<0.05)$ or low satisfaction with life $(p<0.01)$. Women with a low level of self-efficacy chose buttermilk significantly less frequently than those with a moderate $(p<0.0001)$ or high level of this trait $(p<0.001)$. Consumption of natural yoghurt was declared significantly

Table II. Spearman's coefficients of rank correlation between BMI, GSES, LOT-R, and SWLS scales and the frequency of diary product consumption in a group of menopausal women

\begin{tabular}{lcccc}
\hline Product & BMI & GSES & LOT-R & SWLS \\
\hline High-fat milk & 0.0134 & $-0.2643^{* *}$ & $-0.1250^{*}$ & $-0.1252^{*}$ \\
\hline Low-fat milk & -0.1069 & 0.0955 & $-0.1130^{*}$ & $-0.1121^{*}$ \\
\hline High-fat cottage cheese & 0.0374 & $-0.3298^{* *}$ & $-0.2043^{* *}$ & $-0.2523^{* *}$ \\
\hline Low-fat cottage cheese & 0.0571 & $0.1221^{*}$ & 0.0906 & 0.0657 \\
\hline Kefir & $-0.1508^{* *}$ & $0.1402^{*}$ & $0.1321^{*}$ & $0.1339^{*}$ \\
\hline Buttermilk & -0.0400 & $0.1901^{* *}$ & -0.0026 & -0.0087 \\
\hline Natural yoghurt & $-0.1933^{* *}$ & $0.2719^{* *}$ & 0.0838 & 0.0925 \\
\hline Fruit yoghurt & -0.1017 & 0.0624 & $0.1406^{*}$ & $0.1549^{* *}$ \\
\hline${ }^{*}<<0.05,{ }^{* *} p<0.01$ & & & &
\end{tabular}


more often by women with a high rather than by those with a moderate $(p<0.001)$ and low level of self-efficacy $(p=0.0001)$. Fruit yoghurt was drunk significantly less frequently by women with a low rather than moderate level of self-efficacy, and was consumed significantly more often by participants with a high rather than moderate $(p<0.05)$ or low level of optimism $(p<0.01)$, and by those with high rather than moderate $(p<0.05)$ or low satisfaction with life $(p<0.01)$ (Table III).

\section{Discussion}

Overall, our study revealed infrequent consumption of milk and its products by 45-55-year-old women and showed the relationship between the consumption of dairy products and body mass index (BMI) or individual traits, such as the level of self-efficacy, optimism, and satisfaction with life in this population group.

Consumption of dairy products is an important diagnostic marker of nutrition. The positive findings in our group include a high preference for low-fat dairy prod- ucts, including cottage cheese (3.65 vs. 2.78) and milk (3.49 vs. 2.78), and the presence of fermented products (except for buttermilk) in a group of preferred dairy products. This is consistent with dietary guidelines according to which consumption of the low-fat products reduces the supply of saturated fatty acids and cholesterol, both characterized by atherogenic properties [3]. This problem gains particular importance as cardiovascular conditions are a predominant cause of mortality in the Polish population. Arterial hypertension and hyperlipidemia were diagnosed in $25.0 \%$ and $17.1 \%$ of our participants, respectively. Insufficient consumption of dairy products is associated with a reduced supply of calcium, which was reported in various population groups, including menopausal women $[13,14]$, as well as in women with overweight or obesity; additionally, unbalanced calcium to phosphorus ratio was documented in the latter group, enhancing the loss of bone mass [15]. Dietary deficit of calcium and hypolactasia or alactasia are important determinants of osteoporosis; likewise, menopause is a key risk factor for this condition [8]. Aside from

Table III. Frequency of diary product consumption depending on a level of self-efficacy (GSES), optimism (LOT-R) and satisfaction with life (SWLS) in a group of menopausal women

\begin{tabular}{|c|c|c|c|c|c|c|c|c|c|c|}
\hline \multirow{2}{*}{ Product } & & \multicolumn{3}{|c|}{ GSES } & \multicolumn{3}{|c|}{ LOT-R } & \multicolumn{3}{|c|}{ SWLS } \\
\hline & & $x$ & SD & $p$ & $X$ & SD & $p$ & $X$ & SD & $p$ \\
\hline \multirow{3}{*}{ High-fat milk } & $\mathrm{H}$ & 2.15 & 1.70 & \multirow{3}{*}{$<0.0001$} & 2.45 & 1.51 & \multirow{3}{*}{0.0048} & 2.43 & 1.50 & \multirow{3}{*}{0.0045} \\
\hline & $M$ & 3.42 & 1.67 & & 3.19 & 1.70 & & 3.17 & 1.67 & \\
\hline & $\mathrm{L}$ & 2.81 & 1.72 & & 2.76 & 2.15 & & 2.80 & 2.16 & \\
\hline \multirow{3}{*}{ Low-fat milk } & $\mathrm{H}$ & 3.79 & 2.05 & \multirow{3}{*}{0.0371} & 3.39 & 2.01 & \multirow{3}{*}{0.1922} & 3.43 & 2.00 & \multirow{3}{*}{0.1197} \\
\hline & M & 3.42 & 1.99 & & 3.35 & 2.05 & & 3.28 & 2.05 & \\
\hline & $L$ & 3.00 & 2.11 & & 3.81 & 2.12 & & 3.84 & 2.12 & \\
\hline \multirow{3}{*}{$\begin{array}{l}\text { High-fat cottage } \\
\text { cheese }\end{array}$} & $\mathrm{H}$ & 1.91 & 1.24 & \multirow{3}{*}{$<0.0001$} & 2.30 & 1.39 & \multirow{3}{*}{0.0021} & 2.28 & 1.40 & \multirow{3}{*}{0.0014} \\
\hline & $M$ & 3.29 & 1.40 & & 2.85 & 1.64 & & 2.84 & 1.62 & \\
\hline & L & 3.06 & 1.83 & & 3.05 & 1.66 & & 3.05 & 1.65 & \\
\hline \multirow{3}{*}{$\begin{array}{l}\text { Low-fat cottage } \\
\text { cheese }\end{array}$} & $\mathrm{H}$ & 3.79 & 1.23 & \multirow{3}{*}{0.3033} & 3.73 & 1.19 & \multirow{3}{*}{0.2852} & 3.72 & 1.19 & \multirow{3}{*}{0.4268} \\
\hline & $M$ & 3.55 & 1.25 & & 3.50 & 1.22 & & 3.53 & 1.23 & \\
\hline & $\mathrm{L}$ & 3.56 & 1.47 & & 3.71 & 1.49 & & 3.71 & 1.49 & \\
\hline \multirow{3}{*}{ Kefir } & $\mathrm{H}$ & 3.55 & 1.62 & \multirow{3}{*}{0.0693} & 3.39 & 1.54 & \multirow{3}{*}{0.3670} & 3.44 & 1.54 & \multirow{3}{*}{0.3349} \\
\hline & $M$ & 3.35 & 1.62 & & 3.50 & 1.68 & & 3.44 & 1.69 & \\
\hline & $\mathrm{L}$ & 3.00 & 1.63 & & 3.14 & 1.71 & & 3.14 & 1.70 & \\
\hline \multirow{3}{*}{ Buttermilk } & $\mathrm{H}$ & 2.33 & 1.63 & \multirow{3}{*}{$<0.0001$} & 2.21 & 1.67 & \multirow{3}{*}{0.7966} & 2.25 & 1.69 & \multirow{3}{*}{0.8925} \\
\hline & $M$ & 2.55 & 1.67 & & 2.23 & 1.53 & & 2.19 & 1.52 & \\
\hline & $\mathrm{L}$ & 1.44 & 0.94 & & 2.29 & 1.53 & & 2.28 & 1.52 & \\
\hline \multirow{3}{*}{ Natural yoghurt } & $\mathrm{H}$ & 4.21 & 1.56 & \multirow{3}{*}{$<0.0001$} & 3.67 & 1.79 & \multirow{3}{*}{0.7455} & 3.69 & 1.81 & \\
\hline & M & 3.23 & 1.90 & & 3.65 & 1.67 & & 3.63 & 1.66 & 0.6393 \\
\hline & $\mathrm{L}$ & 3.06 & 1.45 & & 3.43 & 1.80 & & 3.42 & 1.79 & \\
\hline & $\mathrm{H}$ & 3.82 & 1.65 & & 4.12 & 1.74 & & 4.13 & 1.75 & \\
\hline Fruit yoghurt & $M$ & 4.00 & 1.65 & 0.0047 & 3.65 & 1.45 & 0.0017 & 3.66 & 1.46 & 0.0015 \\
\hline & $L$ & 3.25 & 1.53 & & 3.38 & 1.63 & & 3.39 & 1.62 & \\
\hline
\end{tabular}

$H$ - high, M- moderate, L - low level of self-efficacy (GSES)/optimism (LOT-R)/satisfaction with life (SWLS); X-arithmetic mean, SD - standard deviation, $p$-significance of differences determined on the Kruskal-Wallis test 
a balanced supply of protein, phosphorus, and vitamin $D$, also a proper saturation of body with calcium is an important inhibitor of skeletal tissue involution during health-oriented training, thus being involved in the secondary prevention of osteoporosis [16]. A Swiss study confirmed that the dietary intervention, namely the administration of dairy products enriched in calcium and vitamin $D$, was reflected by a decreased serum level of biomarker of bone resorption $5 \mathrm{~b}$ TRAP in postmenopausal women; this pointed to a nutrition-related decrease in the rate of bone mass involution $[16,17]$. Our group included $2.0 \%$ of women with confirmed osteoporosis. Aside from calcium, dairy products constitute the main source of riboflavin as well. The study by Pachocka and Kąpiński [15], involving a group of 30-64-year-old women with excessive body weight, revealed that the ingestion of this vitamin is higher in individuals who use hormone replacement therapy. The interest of menopausal women in the consumption of dairy products was also associated with their influence on body weight. One study revealed that an increased supply of calcium is reflected by a normalization of anthropometric indices of nutritional status in Philippinean women [18]. Consequently, modification of calcium supply can be included in a comprehensive strategy of obesity prevention, as this condition increases the risk of other degenerative disorders [18]. Again, the use of hormone replacement therapy can be associated with normalization of the anthropometric indices of nutritional status in women with excessive body weight [15]. Our group included 30.0\% of overweight women and $6.0 \%$ of obese participants. Previous studies confirmed a biologically determined predisposition to weight gain in menopausal women, resulting from hormonal disorders and decreased basal metabolic rate, among others [18]. This is reflected by a high percentage of overweight or obese women over 40 years of age. Our observation on a decrease in BMI associated with a more frequent consumption of kefir and natural yoghurt $(p<0.01)$ seems important in this context, as it confirms the beneficial role of these products in the maintenance of a due body weight. This finding is also important for gynecological practice, as excessive body weight is one of the principal modifiable risk factors for breast and endometrial cancer [4]. Furthermore, the predictive value of obesity with regard to some malignancies, including endometrial and breast cancer, was revealed to increase substantially in postmenopausal women $[4,7]$. A systematic review and meta-analysis of prospective cohort studies of the dietary determinants of female breast cancer confirmed the role of dairy products in the prevention of this malignancy. However, this phenomenon was not documented in the case of milk [19]. Compared to women who consumed dairy products at the lowest frequency, the relative risk of breast cancer in the group of women characterized by the highest consumption amounted to 0.54; the relationship between the consumption of dairy products and breast cancer risk proved stronger in premenopausal than in postmenopausal women [19]. Consequently, an increased consumption of dairy products, but not milk, seems associated with a lower risk of female breast cancer. In spite of a generally low frequency of dairy product consumption in our participants, our findings should be assessed positively in this context, as a tendency to increase the consumption of dairy products (yoghurt and cottage cheese) was documented compared to low-fat milk, as well as a more frequent consumption of kefir than high-fat milk. Also, the excess of saturated fatty acids and trans fatty acids, as well as the deficiency of omega 3 polyunsaturated fatty acids, protein, and soy phytosterols, play an important role in the complex etiology of breast cancer [3]. Moreover, the results of Italian studies point to a possible association between the risk of breast cancer and the diet rich in products with a high glycemic index (GI), in both premenopausal [20] and postmenopausal women [21]. This is consistent with the findings of a Finish study which revealed a role of dietary fiber in decreasing the risk of this malignancy [22]. Also, a French study confirmed an increased risk of breast cancer in postmenopausal women with excessive body weight who preferred products with high $\mathrm{Gl}$, modulating the level of insulin and insulin-like growth factor I (IGF-I) [23]. These findings were confirmed in meta-analysis as well [24]. Furthermore, the results of an American study suggest that a high supply of folic acid is associated with a decreased risk of female breast cancer [25]. This corresponds to Chinese observations according to which a frequent consumption of fruits and vegetables [26], and fermented dairy products [19], also being rich in folic acid, plays a role in the dietary prevention of female breast cancer. Noticeably, milk and its products are also characterized by low $\mathrm{Gl}$.

Moreover, our study revealed statistically significant relationships between analyzed individual traits and dietary choices with regard to the consumption of milk and its products. A more favorable profile of dietary preferences in optimistic women, who were satisfied with life and convinced on their self-efficacy, included a higher consumption of fermented dairy products and less frequent ingestion of milk and highfat cheese. The level of self-efficacy proved the strongest individual determinant of dairy product consumption. It promoted a higher consumption of some fermented dairy products and low-fat cottage cheese, as well as reduced ingestion of milk and high-fat cottage cheese. Taking into account the abovementioned relationships between the preference of milk and its products and the prevention and etiology of female breast cancer [19], it can be assumed that the risk of this condition is higher in women with low levels of self-efficacy, optimism, and satisfaction with life, as they are characterized by a less frequent consumption 
of fermented dairy products, and higher ingestion of milk, especially high-fat milk. Due to an increased supply of atherogenic saturated fatty acids and cholesterol, higher preference of high-fat milk can also increase the risk of degenerative cardiovascular conditions. This was confirmed by different fractions of individuals with BMI greater than $30 \mathrm{~kg} / \mathrm{m}^{2}$ documented in our study in groups with a low and high level of analyzed personality traits: self-efficacy (18.8\% vs. $6.1 \%)$, optimism (9.5\% vs. $0.0 \%)$, and satisfaction with life $(9.4 \%$ vs. $0.0 \%$ ). The relationships documented in our study, which suggest a predictive role of the analyzed psychological traits, can be explained by the characteristics of the latter [12] and are consistent with the results of previous studies. High self-efficacy was proved to promote a more rapid reduction of excessive body weight in postmenopausal women subjected to dietary intervention [27]. An American study [28] analyzing the relationship between the level of optimism/pessimism and the hemostasis system of individuals between 45 and 84 years of age revealed a lower concentration of fibrinogen and homocysteine in more optimistic participants; consequently, optimism seems to decrease the risk of cardiovascular disorders, which is consistent with a less frequent consumption of milk $(p<0.05)$ and high-fat cottage cheese $(p<0.01)$ among more optimistic women taking part in our study. A substantial indirect influence of the level of self-efficacy on a dietary supply of calcium $(p<0.05)$ was also documented in a group of American adolescent girls [29].

Cognitive and behavioral activities strengthening self-efficacy and optimism, and increasing the level of satisfaction with life can be useful in the improvement of nutrition, also in menopausal women. A study of women from Iran revealed that health education and resultant rationalization of the style of life belong to the factors promoting the internal control of health and self-efficacy [30]. Therefore, consideration of psychosocial variables can constitute an important aspect of rational nutrition and efficient dietary intervention, and can indirectly improve one's health potential. This problem is particularly important in the case of menopausal women, due to their increased risk of chronic disorders in the etiology of which environmental factors, including diet, play a vital role [6]. Also, other authors postulate covering menopausal women with complex medical, dietary and psychological counseling [11].

\section{Conclusions}

1. In view of its health consequences reported in the literature, the low frequency of dairy product consumption among perimenopausal women taking part in our study could reduce the effectiveness of the secondary prevention of osteoporosis and increase the risk of breast cancer in this population group.
2. An inverse correlation observed between body mass index (BMI) and consumption of kefir and natural yoghurt points to the important role of fermented dairy products in the maintenance of due weight in perimenopausal women at risk of overweight and obesity.

3. Statistically significant relationships were documented between the frequency of dairy product consumption and analyzed individual traits, suggesting that women with a high level of self-efficacy, optimism, and satisfaction with life are predisposed to more rational dietary choices.

\section{References}

1. Całyniuk B, Grochowska-Niedworok E, Białek A et al. Food guide pyramid - its past and present. Probl Hig Epidemiol 2011; 92: 20-4.

2. Kunachowicz H, Nadolna I, Przygoda B et al. Food composition tables. Wyd. PZWL, Warszawa 2005. [in Polish]

3. Kłosiewicz-Latoszek L. Dietary guidelines in prevention of chronic diseases. Probl Hig Epidemiol 2009; 90: 447-50. [in Polish]

4. Pischon T, Nöthlings $U$, Boeing $H$. Obesity and cancer. Proc Nutr Soc 2008; 67: 128-45.

5. Stachowiak G, Zając A, Pertyński T. Metabolic syndrome in women in the menopausal period. Przegl Menopauz 2009; 1: 6-10. [in Polish]

6. Pachocka L. Comparative analysis of lifestyle obese women before menopause and perimenopause period. Rocz Panstw Zakl Hig 2010; 61: 389-93. [in Polish]

7. Szosland J, Kokoszko A, Zasada K et al. Obesity as a risk factor for oxidative damage to membrane lipids in postmenopausal women. Przegl Menopauz 2010; 3: 159-64. [in Polish]

8. Tkaczuk-Włach J, Sobstyl M, Jakiel G. Osteoporosis - clinical features, risk factors and diagnostics. Przegl Menopauz 2010; 2: 113-7. [in Polish]

9. Pilska M, Jeżewska-Zychowicz M. Psychology of nutrition. Selected issues. Wyd. SGGW, Warszawa 2008. [in Polish]

10. Remick AK, Polivy J, Pliner P. Internal and external moderators of the effect of variety on food intake. Psychol Bull 2009; 135: 434-51.

11. Bąk-Sosnowska M, Skrzypulec-Plinta V. The reasons for excessive body mass in menopausal women. Przegl Menopauz 2012; 1: 31-5. [in Polish]

12. Juczyński Z. Measurement tools in health promotion and health psychology. Pracownia Testów Psychologicznych, Warszawa 2009. [in Polish]

13. Włodarek D, Sobocińska A, Głąbska D. Dairy calcium intake in diet of women aged over 60. Bromat Chem Toksykol 2012; 45: 833-8. [in Polish]

14. Fardellone P, Cotte FE, Roux C et al. Calcium intake and the risk of osteoporosis and fractures in French women. Joint Bone Spine 2010; 77: $154-8$.

15. Pachocka LM, Kąpiński JL. Effect of the hormone therapy on the nutritional status and body composition of women aged 30-64 years with BMI > 25. Przegl Menopauz 2011; 1: 15-9. [in Polish]

16. Bonjour JP, Benoit V, Rousseau B et al. Consumption of vitamin D-and calcium-fortified soft white cheese lowers the biochemical marker of bone resorption TRAP $5 b$ in postmenopausal women at moderate risk of osteoporosis fracture. J Nutr 2012; 142: 698-703.

17. Bonjour JP, Benoit V, Pourchaire $\mathrm{O}$ et al. Inhibition of markers of bone resorption by consumption of vitamin $\mathrm{D}$ and calcium-fortified soft plain cheese by institutionalised elderly women. Br J Nutr 2009; 102: 962-6.

18. Angeles-Agdeppa I, Capanzana MV, Li-Yu J et al. High-calcium milk prevents overweight and obesity among postmenopausal women. Food Nutr Bull 2010; 31: 381-90.

19. Dong JY, Zhang L, He K et al. Dairy consumption and risk of breast cancer: a meta-analysis of prospective cohort studies. Breast Cancer Res Treat 2011; 127: 23-31.

20. Sieri S, Pala V, Brighenti F et al. Dietary glycemic index, glycemic load, and the risk of breast cancer in an Italian prospective cohort study. Am J Clin Nutr 2007; 86: 1160-6.

21. Silvera SA, Jain M, Howe GR et al. Dietary carbohydrates and breast cancer risk: a prospective study of the roles of overall glycemic index and glycemic load. Int J Cancer 2005; 114: 653-8. 
22. Aubertin-Leheudre $M$, Hämäläinen $E$, Adlercreutz H. Diets and hormonal levels in postmenopausal women with or without breast cancer. Nutr Cancer 2011; 63: 514-24.

23. Lajous M, Boutron-Ruault MC, Fabre A et al. Carbohydrate intake, glycemic index, glycemic load, and risk of postmenopausal breast cancer in a prospective study of French women. Am J Clin Nutr 2008; 87: 1384-91.

24. Dong JY, Qin LQ. Dietary glycemic index, glycemic load, and risk of breast cancer: meta-analysis of prospective cohort studies. Breast Cancer Res Treat 2011; 126: 287-94.

25. Shrubsole MJ, Shu XO, Li HL et al. Dietary B vitamin and methionine intakes and breast cancer risk among Chinese women. Am J Epidemiol 2011; 173: 1171-82.

26. Bao PP, Shu XO, Zheng Y et al. Fruit, vegetable, and animal food intake and breast cancer risk by hormone receptor status. Nutr Cancer 2012; 64: 806-19.

27. Shin H, Shin J, Liu PY et al. Self-efficacy improves weight loss in overweight/obese postmenopausal women during a 6-month weight loss intervention. Nutr Res 2011; 31: 822-8.

28. Roy B, Diez-Roux AV, Seeman T et al. Association of optimism and pessimism with inflammation and hemostasis in the Multi-Ethnic Study of Atherosclerosis (MESA). Psychosom Med 2010; 72: 134-40.

29. Sharma SV, Hoelscher DM, Kelder SH et al. Psychosocial factors influencing calcium intake and bone quality in middle school girls. J Am Diet Assoc 2010; 110: 932-6.

30. Bastani F, Hashemi S, Bastani N et al. Impact of preconception health education on health locus of control and self-efficacy in women. East Mediterr Health J 2010; 16: 396-401. 